\title{
The Influence of Ripeness on the Phenolic Content, Antioxidant and Antimicrobial Activities of Pumpkins (Cucurbita moschata Duchesne)
}

\author{
Meriem Mokhtar ${ }^{1, *,+} \mathbb{D}$, Sarah Bouamar ${ }^{1,+}$, Arianna Di Lorenzo ${ }^{2}$, Caterina Temporini ${ }^{3}$, Maria Daglia ${ }^{4,5, \ddagger(\mathbb{D})}$ \\ and Ali Riazi $1, \ddagger$
}

check for

updates

Citation: Mokhtar, M.; Bouamar, S.; Di Lorenzo, A.; Temporini, C.;

Daglia, M.; Riazi, A. The Influence of Ripeness on the Phenolic Content, Antioxidant and Antimicrobial Activities of Pumpkins (Cucurbita moschata Duchesne). Molecules 2021, 26, 3623. https://doi.org/10.3390/ molecules 26123623

Academic Editor: Francesco Cacciola

Received: 27 May 2021

Accepted: 9 June 2021

Published: 13 June 2021

Publisher's Note: MDPI stays neutral with regard to jurisdictional claims in published maps and institutional affiliations.

Copyright: (c) 2021 by the authors. Licensee MDPI, Basel, Switzerland. This article is an open access article distributed under the terms and conditions of the Creative Commons Attribution (CC BY) license (https:/ / creativecommons.org/licenses/by/ $4.0 /)$.
1 Laboratory of Beneficial Microorganisms, Functional Food and Health (LMBAFS), University of Abdelhamid Ibn Badis, Mostaganem 27000, Algeria; sarah.bouamar@univ-mosta.dz (S.B.); ali.riazi@univ-mosta.dz (A.R.)

2 Department of Drug Sciences, Medicinal Chemistry and Pharmaceutical Technology, University of Pavia, Via Taramelli 12, 27100 Pavia, Italy; arianna.dilorenzo01@universitadipavia.it

3 Department of Drug Sciences and Italian Biocatalysis Center, University of Pavia, Via Taramelli, 12, 27100 Pavia, Italy; caterina.temporini@unipv.it

4 Department of Pharmacy, University of Naples "Federico II", 80131 Naples, Italy; maria.daglia@unina.it

5 International Research Center for Food Nutrition and Safety, Jiangsu University, Zhenjiang 212013, China

* Correspondence: meriem.mokhtar@univ-mosta.dz

+ These authors contributed equally to this work.

$\ddagger$ These authors contributed equally to this work.

Abstract: Cucurbita moschata Duchesne (Cucurbitaceae) is a plant food highly appreciated for the content of nutrients and bioactive compounds, including polyphenols and carotenoids, which contribute to its antioxidant and antimicrobial capacities. The purpose of this study was to identify phenolic acids and flavonoids of Cucurbita moschata Duchesne using high-performance liquid chromatographydiode array detection-electrospray ionization tandem mass spectrometry (HPLC-DAD-ESI-MS) at different ripening stages (young, mature, ripened) and determine its antioxidant and antimicrobial activities. According to the results, phenolic acids and flavonoids were dependent on the maturity stage. The mature fruits contain the highest total phenolic and flavonoids contents (97.4 mg GAE. $100 \mathrm{~g}^{-1}$ and $28.6 \mathrm{mg}$ QE. $\left.100 \mathrm{~g}^{-1}\right)$.A total of 33 compounds were identified. Syringic acid was the most abundant compound (37\%), followed by cinnamic acid (12\%) and protocatechuic acid (11\%). Polyphenol extract of the mature fruits showed the highest antioxidant activity when measured by DPPH $(0.065 \mu \mathrm{mol} \mathrm{TE} / \mathrm{g})$ and ABTS $(0.074 \mu \mathrm{mol} \mathrm{TE} / \mathrm{g})$ assays. In the antimicrobial assay, the second stage of ripening had the highest antibacterial activity. Staphylococcus aureus was the most sensitive strain with an inhibition zone of $12 \mathrm{~mm}$ and a MIC of $0.75 \mathrm{mg} \mathrm{L}^{-1}$. The lowest inhibition zone was obtained with Salmonella typhimurium $(5 \mathrm{~mm})$, and the MIC value was $10 \mathrm{mg} \mathrm{L}^{-1}$.

Keywords: Cucurbita moschata; polyphenols; ripening; antioxidant; antimicrobial

\section{Introduction}

According to several epidemiological studies, the consumption of fruits and vegetables exert protective effects against several risk factors of chronic diseases because of their content of micronutrients, dietary fiber, and phytochemicals [1-5]. In addition, the interest in plant foods is also due to their antioxidant and antimicrobial properties that make plant extracts able to act against both lipid peroxidation and foodborne bacteria. Considering the growing demand to replace synthetic preservatives such as methylparabens with natural substances, research on preservatives is of great interest to the food and cosmetic industry [6-9].

Pumpkin, Cucurbita moschata Duchesne (Cucurbitaceae), is an essential source of many antioxidant nutrients such as polyphenols and carotenoids and is cultivated in warm areas 
all over the world [10,11]. There are several culinary uses of squashes; they can be used as a vegetable or as an ingredient in food preparations $[12,13]$. In addition, pumpkin fruits are rich in many essential compounds for the human body, such as eight amino acids, vitamins (A, B, C), various minerals, carotene, and trace elements (phosphorus, potassium, calcium, magnesium, zinc, and silicon) [14].

The chemical composition and biological properties of different parts of $C$. moschata have been examined in many investigations confirming that pumpkins have a wide range of bioactivities, such as anti-diabetes, anti-inflammation, hepatoprotective, anticancer, and anti-obesity properties [15-22]. These properties are generally attributedto the content of phenolic acids [23].

Ten days after pollination, the fruit is characterized by a small volume and has reached the young fruit stage. Twenty days after flowering, a rapid increase of size and accumulation of metabolites occurs, and the pumpkin fruit enters the expanding stage. Ten days later, the fruit enters a premature stage reaching a maximum volume. Forty days after flowering, the fruit is considered to be fully mature. Once the fruit comes to its full size (50 days), the ripening process is initiated, and significant biochemical changes occur in the maturing fruit, which is associated with further dramatic changes in color, sweetness, and fruit texture [24].

Several intrinsic and extrinsic factors can influence polyphenol quality and quantity, including plant genetics, growing conditions (temperature, light, water, soil type, mineral nutrients, oxygen), and physiological maturity [25-27]. Some biochemical, physiological, and structural modifications occur during ripening and affect the quality of the fruits.The fruit undergoes some changes in gene expression level, resulting in some desirable variations such as texture and firmness, sugar accumulation, organic acid reduction, pigment changes that lead to the development of color, and volatile compounds responsible for flavor and aroma [28]. As reported in the literature, the phytochemistry variation depends on the phytochemical's biosynthesis during plant growth and their changes during physiological maturity [29].

The knowledge of the chemical composition and functional properties during ripening is essential to characterize the perfect harvesting time and maximize the antimicrobial and antioxidant properties to exploit a plant extract as a food preservative. Considering that no previous study has been conducted on identifying individual phenolic compounds of $C$. moschat $a$ during maturation, this work aimed to study the phenolic profile changes during ripening, besides the development of antioxidant and antimicrobial activities.

\section{Results}

\subsection{Total Polyphenols and Flavonoids}

Fruits and vegetables containing polyphenols are considered significant dietary sources of health-promoting components. The total phenolic and flavonoid content in pumpkins at the three stages of ripeness were estimated using the Folin-Ciocalteu and aluminum chloride colorimetric methods.

Our results showed that pumpkin total phenolic and flavonoid contents are dependent on the fruit maturity stage (Table 1). The unripe stage contains a good quantity of total polyphenols (77.5 mg GAE. $100 \mathrm{~g}^{-1} \mathrm{FW}$ ) and flavonoids (23.4 mg QE. $100 \mathrm{~g}^{-1} \mathrm{FW}$ ). These amounts increased with the fruit ripeness and were 26 and $22 \%$ higher in the second stage than unripe fruits (97.4 mg GAE. $100 \mathrm{~g}^{-1}$ and $28.6 \mathrm{mg}$ QE. $100 \mathrm{~g}^{-1}$ ).

Table 1. Total polyphenols and flavonoids of $C$. moschata at three stages of ripeness.

\begin{tabular}{|c|c|c|}
\hline Stages of Ripeness & $\begin{array}{c}\text { Total Polyphenols } \\
\text { (mg GAE. } 100 \mathrm{~g}^{-1} \text { FW) }\end{array}$ & $\begin{array}{c}\text { Total Flavonoids } \\
\left(\mathrm{mg} \mathrm{QE} .100 \mathrm{~g}^{-1} \mathrm{FW}\right)\end{array}$ \\
\hline Young & $77.50 \pm 1.01$ & $23.47 \pm 0.90$ \\
\hline Mature & $97.43 \pm 2.20$ & $28.66 \pm 0.33$ \\
\hline Ripened & $55.60 \pm 3.60$ & $19.60 \pm 1.25$ \\
\hline
\end{tabular}


At the end of fruit ripeness, the levels of both polyphenols and flavonoids decrease (55.6 mg GAE. $100 \mathrm{~g}^{-1}$ and $19.6 \mathrm{mg} \mathrm{QE} .100 \mathrm{~g}^{-1}$ ). These findings suggest that the phenolic content increase during the first stages of maturity, but these levels start to drop off with the ripeness of the fruit. The decrease in total phenolic content during fruit maturity was referred to as the oxidation of polyphenols by polyphenol-oxidase [30,31].

Oloyede et al. [32] found that mature pumpkin fruits have a 71\% higher polyphenol content than young pumpkin fruits. Proanthocyanidin, anthocyanin, and flavonoid concentrations were also more important in mature fruits $(17 \%, 14 \%$, and $4.5 \%$, respectively). The phenolic contents of their immature and mature samples were 10.3 and $33.5 \mathrm{mg} / 100 \mathrm{~g}$. For the flavonoids, 5.4 and $6.0 \mathrm{mg} / 100 \mathrm{~g}$ were calculated. The total content of polyphenols and flavonoids obtained in our samples was more important but lower than that reported by Zdunić et al. [33] (90.59 mg/100 g).

A series of complex biochemical reactions occur during fruit ripening that leads to the production of phenolic compounds, carotenoids, and volatile compounds [34]. Several factors are responsible for the qualitative and quantitative differences of the above-listed phytochemicals, such as sunlight, soils, season, cultivation area, variety of fruit, and maturity stages [35].

\subsection{Analysis of Polyphenols by HPLC-PDA-ESI-MS}

In an attempt to characterize polyphenols in the three stages of maturity of pumpkin fruits, other polar compounds were also identified. The phenolic profile at the three stages of ripeness of pumpkins is presented in Figure 1. A total of 33 compounds were identified, and among them, phenolic acids are the main components (Table 2). Phenolic acids represent approximately $30 \%$ of the dietary polyphenols and are present in both free and bound forms in plants [36].

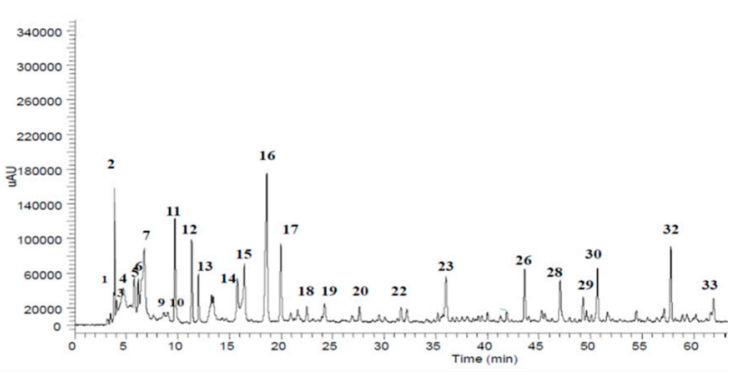

(A)

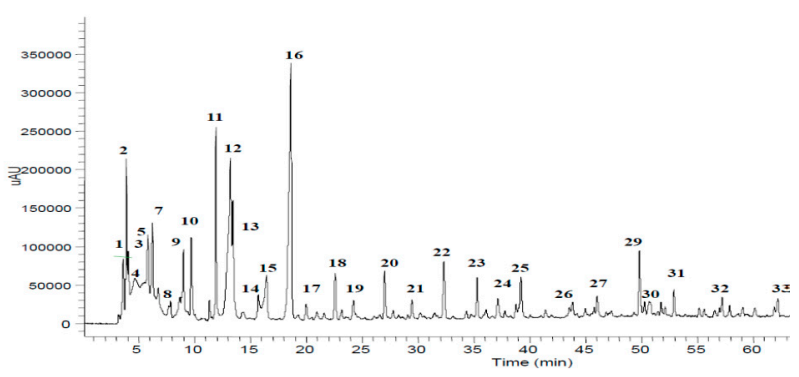

(B)

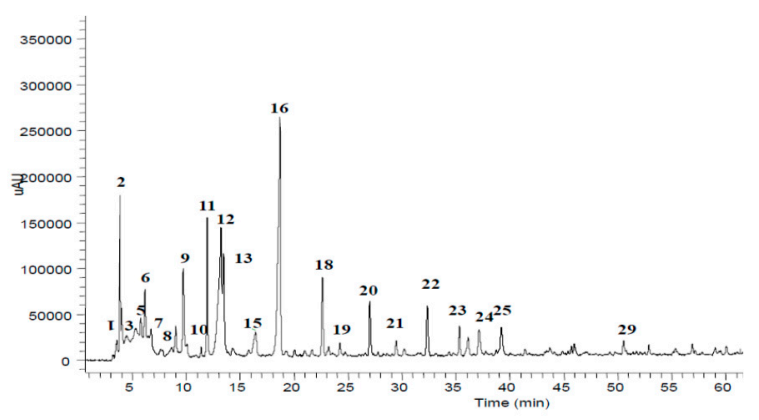

(C)

Figure 1. Identification of C. moschata polyphenols in (A) young, (B) mature, and (C) ripened fruits.

These results are consistent with previous studies in different varieties of pumpkins $[20,37,38]$. Although several works have reported the presence of chlorogenic acid $[11,23,39]$, it was not detected in our sample. Some flavonoids were also identified in pumpkin extracts, mainly quercetin glucoside. In addition, another phenolic compound 
belonging to the lignan class was identified (Lariciresinol-sesquilignan). This compound has already been reported in other researches on pumpkins $[40,41]$.

Table 2. Identification of C. moschata polyphenols by HPLC-DAD-ESI-MS.

\begin{tabular}{|c|c|c|c|c|c|}
\hline $\mathbf{N}$ & RT & Molecular Formula & {$[\mathbf{M}-\mathbf{H}]^{-}$} & MS $^{2}$ & Compounds \\
\hline 1 & 3.60 & $\mathrm{C}_{9} \mathrm{H}_{8} \mathrm{O}_{4}$ & 215 & 215179100135 & Caffeic acid derivative \\
\hline 2 & 3.83 & $\mathrm{C}_{15} \mathrm{H}_{18} \mathrm{O}_{8}$ & 325 & 163119 & $p$-comaroylhexoside \\
\hline 3 & 4.01 & $\mathrm{C}_{5} \mathrm{H}_{11} \mathrm{NO}_{2}$ & 116 & 1166983 & Valine \\
\hline 4 & 4.62 & $\mathrm{C}_{4} \mathrm{H}_{9} \mathrm{NO}_{3}$ & 118 & 11810172 & threonine \\
\hline 5 & 5.78 & $\mathrm{C}_{8} \mathrm{H}_{8} \mathrm{O}_{3}$ & 151 & 151 & vanillin \\
\hline 6 & 6.18 & $\mathrm{C}_{11} \mathrm{H}_{14} \mathrm{O}_{4}$ & 209 & 209 & Sinapyl alcohol \\
\hline 7 & 6.75 & $\mathrm{C}_{11} \mathrm{H}_{12} \mathrm{O}_{5}$ & 223 & 180195 & Sinapic acid \\
\hline 8 & 9.00 & $\mathrm{C}_{14} \mathrm{H}_{14} \mathrm{O}_{8}$ & 505 & 179132 & Feruloyl malate \\
\hline 9 & 9.72 & $\mathrm{C}_{4} \mathrm{H}_{7} \mathrm{NO}_{4}$ & 132 & 13286 & Aspartic acid \\
\hline 10 & 11.32 & $\mathrm{C}_{9} \mathrm{H}_{11} \mathrm{NO}_{3}$ & 180 & 180 & Tyrosine \\
\hline 11 & 11.99 & $\mathrm{C}_{7} \mathrm{H}_{6} \mathrm{O}_{4}$ & 153 & 111109 & Protocatechuic acid \\
\hline 12 & 13.22 & $\mathrm{C}_{9} \mathrm{H}_{8} \mathrm{O}_{2}$ & 147 & & cinnamic acid \\
\hline 13 & 13,44 & $\mathrm{C}_{4} \mathrm{H}_{6} \mathrm{O}_{6}$ & 149 & & Tartaric acid \\
\hline 14 & 15.73 & $\mathrm{C}_{7} \mathrm{H}_{6} \mathrm{O}_{4}$ & 157 & 109 & Protocatechuic acid derivate \\
\hline 15 & 16.46 & $\mathrm{C}_{10} \mathrm{H}_{13} \mathrm{~N}_{5} \mathrm{O}_{4}$ & 266 & 136 & adenosine \\
\hline 16 & 18.63 & $\mathrm{C}_{9} \mathrm{H}_{10} \mathrm{O}_{5}$ & 197 & 166120 & syringic acid \\
\hline 17 & 19.97 & $\mathrm{C}_{9} \mathrm{H}_{11} \mathrm{NO}_{2}$ & 164 & 120 & Phenylalanine \\
\hline 18 & 22.59 & $\mathrm{C}_{10} \mathrm{H}_{12} \mathrm{O}_{4}$ & 195 & 181 & Dihydroferulic acid derivative \\
\hline 19 & 24.23 & $\mathrm{C}_{9} \mathrm{H}_{8} \mathrm{O}_{3}$ & 163 & & coumaric acid \\
\hline 20 & 27.62 & $\mathrm{C}_{9} \mathrm{H}_{8} \mathrm{O}_{4}$ & 179 & & caffeic acid \\
\hline 21 & 29.46 & $\mathrm{C}_{10} \mathrm{H}_{12} \mathrm{O}_{4}$ & 195 & 178 & Dihydroferulic acid \\
\hline 22 & 32.32 & $\mathrm{C}_{9} \mathrm{H}_{10} \mathrm{O}_{4}$ & 181 & & Syringaldehyde \\
\hline 23 & 35.99 & $\mathrm{C}_{10} \mathrm{H}_{10} \mathrm{O}_{4}$ & 193 & & Ferulic acid \\
\hline 24 & 37.14 & $\mathrm{C}_{15} \mathrm{H}_{14} \mathrm{O}_{6}$ & 289 & & Catechin \\
\hline 25 & 39.22 & $\mathrm{C}_{13} \mathrm{H}_{8} \mathrm{O}_{6}$ & 259 & 215187231 & 1,3,5,6-tetrahydroxyxanthone \\
\hline 26 & 43.63 & $\mathrm{C}_{13} \mathrm{H}_{12} \mathrm{O}_{9}$ & 311 & & Caftaric acid \\
\hline 27 & 46.06 & $\mathrm{C}_{22} \mathrm{H}_{18} \mathrm{O}_{11}$ & 457 & & Gallocatechin gallate \\
\hline 28 & 47.07 & $\mathrm{C}_{30} \mathrm{H}_{36} \mathrm{O}_{10}$ & 555 & & Lariciresinol-sesquilignan \\
\hline 29 & 49.83 & $\mathrm{C}_{21} \mathrm{H}_{20} \mathrm{O}_{12}$ & 463 & 301 & Quercetin glucoside \\
\hline 30 & 50.69 & $\mathrm{C}_{22} \mathrm{H}_{18} \mathrm{O}_{10}$ & 441 & 539 & Epicatechin gallate \\
\hline 31 & 52.92 & $\mathrm{C}_{21} \mathrm{H}_{18} \mathrm{O}_{12}$ & 461 & & Luteolin-7-O-glucuronide \\
\hline 32 & 57.79 & $\mathrm{C}_{21} \mathrm{H}_{19} \mathrm{O}_{12}$ & 455 & 301 & Quercetin-hexoside \\
\hline 33 & 62.21 & $\mathrm{C}_{21} \mathrm{H}_{19} \mathrm{O}_{11}$ & 593 & 285 & Luteolin-7-O-rutinoside \\
\hline
\end{tabular}

For the other polar compounds, five amino acids were detected (valine, threonine, tyrosine, phenylalanine, and aspartic acid), two organic acids (tartaric acid and feruloyl malate), and one glycosylamine (adenosine). These polar compounds were also described in a previous work conducted by Iswaldi et al. [42] in Cucurbita pepo.

Quantitative determination of pumpkin polyphenols was performed by interpolation of the calibration curves, and the results $(\mu \mathrm{g} / \mathrm{g} \pm \mathrm{SD})$ are reported in Table 3. Syringic acid 
was the most abundant compound representing $37 \%$ of the phenolic compounds of pumpkins, followed by cinnamic acid $(11.93 \%)$, protocatechuic acid (11.30), $p$-comaroylhexoside $(4.71 \%)$, quercetin glucoside $(4.53 \%)$, and vanillin $(4.29 \%)$.

Table 3. Quantification of C. moschata polyphenols in young, mature and ripened fruits $(\mu \mathrm{g} / \mathrm{g})$.

\begin{tabular}{|c|c|c|c|c|}
\hline $\mathbf{N}$ & Compounds & Young & Mature & Ripened \\
\hline 1 & Caffeic acid derivative & $23.80 \pm 1.41$ & $102.58 \pm 8.69$ & $33.64 \pm 2.60$ \\
\hline 2 & $p$-comaroylhexoside & $75.32 \pm 2.17$ & $171.14 \pm 10.57$ & $92.89 \pm 5.84$ \\
\hline 3 & Vanillin & $10.74 \pm 1.85$ & $156.10 \pm 7.69$ & $43.99 \pm 4.41$ \\
\hline 4 & Sinapicacid & $136.92 \pm 8.21$ & $27.16 \pm 1.58$ & $16.27 \pm 1.41$ \\
\hline 5 & Protocatechuicacid & $96.90 \pm 3.47$ & $410.31 \pm 13.99$ & $229.46 \pm 14.75$ \\
\hline 6 & Cinnamic acid & $43.04 \pm 2.84$ & $433.48 \pm 19.27$ & $316.46 \pm 13.86$ \\
\hline 7 & Protocatechuic acid derivate & $228.79 \pm 17.15$ & $85.92 \pm 4.31$ & - \\
\hline 8 & Syringic acid & $604.24 \pm 18.55$ & $1340.59 \pm 28.12$ & $998.55 \pm 13.54$ \\
\hline 9 & $\begin{array}{l}\text { Dihydroferulic acid } \\
\text { derivative }\end{array}$ & $37.44 \pm 2.38$ & $105.66 \pm 7.54$ & $156.87 \pm 8.78$ \\
\hline 10 & Coumaric acid & $33.33 \pm 2.24$ & $52.56 \pm 4.87$ & $30.56 \pm 2.86$ \\
\hline 11 & Caffeic acid & $29.79 \pm 1.79$ & $106.80 \pm 7.71$ & $85.67 \pm 5.88$ \\
\hline 12 & Dihydroferulic acid & - & $41.06 \pm 3.15$ & $29.64 \pm 2.45$ \\
\hline 13 & Ferulic acid & $112.42 \pm 7.98$ & $85.24 \pm 4.55$ & $57.51 \pm 3.84$ \\
\hline 14 & Catechin & - & $45.95 \pm 2.21$ & $59.79 \pm 4.86$ \\
\hline 15 & Caftaric acid & $106.49 \pm 9.15$ & $43.35 \pm 3.95$ & - \\
\hline 16 & (-)-Gallocatechin gallate & - & $41.21 \pm 2.87$ & - \\
\hline 17 & Quercetin glucoside & $77.38 \pm 5.66$ & $164.66 \pm 11.74$ & $46.98 \pm 3.27$ \\
\hline 18 & (-)-Epicatechin gallate & $75.80 \pm 5.12$ & $42.19 \pm 2.13$ & - \\
\hline 19 & Luteolin 7-O-glucuronide & - & $71.35 \pm 5.62$ & - \\
\hline 20 & Quercetin hexoside & $127.02 \pm 9.56$ & $37.03 \pm 1.18$ & - \\
\hline 21 & Luteolin-7-O-rutinoside & $65.15 \pm 4.36$ & $66.52 \pm 3.49$ & - \\
\hline
\end{tabular}

Fruit or other plant tissue maturation involves a series of complex reactions which lead to changes in the plant's phytochemistry. Two distinct phenomena of phenolic content change were observed during ripeness: a steady decrease $[43,44]$ or an increase at the end of ripeness $[45,46]$.

According to the results, some phenolic acids such as (caffeic acid, caffeic acid derivative, protocatechuic acid, cinnamic acid, syringic acid, coumaric acid, dihydroferulic acid, p-comaroylhexoside, and vanillin) and flavonoid compounds (quercetin glucoside, luteolin 7-O-glucuronide, luteolin-7-O-rutinoside, and (-)-gallocatechin gallate) significantly increase from young to mature stages. However, those levels are reduced in the ripened fruits $(p<0.05)$.

The concentrations of dihydroferulic acid derivative and catechin continue to increase from young to ripened fruits $(p<0.05)$; they were $48 \%$ and $30 \%$ higher than the levels obtained in the mature fruits.Ndri et al. [47] studied polyphenols at different ripeness stages in Gnagnan (Solanum indicum L.) berries. Their results suggest that as maturity progresses, the amount of phenolic acids increases. These results are, in general, similar to those found in the present study.

Previous research carried out by Gündoğdu et al. [48] has reported similar findings. These authors studied the development of phenolic compounds during three maturity 
stages in apricots (Rosaceae). They noticed that the mid-ripe stage was the richest in both phenolic acids and flavonoids.

On the other hand, the amounts of sinapic acid, ferulic acid, caftaric acid, protocatechuic acid derivate, $(-)$-epicatechin gallate, and quercetin-hexosidewere the highest in the first stage and decreased with maturity $(p<0.05)$.

\subsection{Antioxidant Activity}

Oxidation is considered a major cause of food and food product deterioration. Different assays describing the capability of redox molecules to scavenge free radicals to measure the antioxidant capacity of food and biological samples can be found in the literature [49-51].

The mature stage showed the highest antioxidant activity compared to the other stages when measured by DPPH $(0.065 \pm 0.010 \mu \mathrm{mol} \mathrm{TE} / \mathrm{g})$, and ABTS $(0.074 \pm 0.021 \mu \mathrm{mol} \mathrm{TE} / \mathrm{g})$ assays (Table 4). By contrast, the pumpkin ripened stage exerted the lowest antioxidant activity with a loss of $37 \%$ and $27 \%$ in the DPPH and ABTS tests. Thus, the antioxidant activity reduction during pumpkin fruit maturation may be associated with the relative decrease in the content of various polyphenol compounds [52,53].

Table 4. Antioxidant activity of different maturity stages of C. moschata polyphenols.

\begin{tabular}{ccc}
\hline Stages of Ripeness & $\begin{array}{c}\text { DPPH } \\
\left(\boldsymbol{\mu} \mathbf{m o l ~ T E ~} \mathbf{~ g}^{-\mathbf{1}} \mathbf{F W}\right)\end{array}$ & $\begin{array}{c}\text { ABTS } \\
\left(\boldsymbol{\mu} \mathbf{m o l ~ T E ~} \mathbf{~}^{-\mathbf{1}} \mathbf{F W}\right)\end{array}$ \\
\hline Young & $0.053 \pm 0.008$ & $0.067 \pm 0.048$ \\
Mature & $0.065 \pm 0.010$ & $0.074 \pm 0.021$ \\
Ripened & $0.048 \pm 0.005$ & $0.055 \pm 0.003$ \\
\hline
\end{tabular}

A positive correlation is observed between the antioxidant capacity of pumpkin polyphenols at different stages of fruit maturation in relation to total phenolic and flavonoid contents. Both DPPH and ABTS are strongly correlated with total polyphenols $\left(\mathrm{R}^{2}=0.996\right.$ and $\left.R^{2}=0.984\right)$ and flavonoids $\left(R^{2}=0.997\right.$ and $\left.R^{2}=0.945\right)$ respectively.

Due to their capacity to donate hydrogen atoms to free radicals, phenolic and flavonoid molecules are significant antioxidant components that deactivate free radicals. They also have excellent structural properties for scavenging free radicals. Several studies have reporteda linear correlation between total phenolic and flavonoid contents and antioxidant activity. By analyzing the correlation coefficients (R-values), we can suggest that phenolic and flavonoid compounds are responsible for the antioxidant activity of the pumpkin extracts [54].

Syringic acid was identified as the major phenolic compound pumpkins with 37\%. It is a natural phenolic acid found in many fruits and vegetables such as pumpkins, olives, grapes, rice, wheat, oats, maize, sorghum, sugar cane, and honey [55,56]. Many studies reported its biological activities, including antioxidant properties, anticancer, antiinflammation, anti-diabetic, and antimicrobial [57-60]. In addition, several studies indicated that syringic acid exhibits an excellent radical scavenging activity against $\beta$-carotene and 2,2-diphenyl-1-picrylhydrazyl (DPPH) [55].

Cinnamic acid, among the most abundant polyphenols identified in our sample, is a natural aromatic carboxylic acid found in several plants such as Chinese cinnamon, ginseng, fruits, vegetables, whole grains, and honey $[61,62]$. According to the literature, cinnamic acid exhibits antioxidant, antimicrobial, anticancer, neuroprotective, anti-inflammatory, and anti-diabetic properties [63-67]. The antioxidant properties of cinnamic acid are attributed to its ability to end radical chain reactions by donating electrons that react with radicals forming stable products $[62,68]$.

Protocatechuic acid (3,4-dihydroxybenzoic acid), also found in pumpkins, is a catecholtype phenolic acid that naturally exists in many fruits and vegetables and is known to have antibacterial, anti-mutagenic, anti-inflammatory, and anti-hyperglycemic properties. It has also been recognized as an effective antioxidant agent against oxidative stress, preventing several pathologies $[69,70]$. 


\subsection{Antimicrobial Activity}

Food deterioration during storage is a significant problem and concern for the food industry. Spoilage microorganisms are responsible for product degradation and short shelf-life. Over the last decade, the food and cosmetic industries have tried to reduce the use of chemical preservatives in response to the increasing demand for natural compounds with antimicrobial activity [71]. The obtained results of the filter disc are shown in Table 5.

Table 5. Antimicrobial activity of different maturity stages of C. moschata polyphenols.

\begin{tabular}{|c|c|c|c|c|}
\hline Strains & Young (mm) & Mature (mm) & Ripened (mm) & $\operatorname{MIC}\left(\mathrm{mg} \mathrm{L}^{-1}\right)$ \\
\hline E. hirae & $6 \pm 0$ & $7.16 \pm 0.38$ & $4 \pm 0$ & 2.5 \\
\hline P. mirabilis & $4.16 \pm 0.32$ & $5.33 \pm 0.50$ & $3.33 \pm 1.25$ & 5 \\
\hline B. subtilis & $5 \pm 0$ & $6.25 \pm 0.25$ & $3.75 \pm 0.89$ & 5 \\
\hline P. aeruginosa & $4.75 \pm 2.57$ & $6 \pm 0$ & $3.5 \pm 0.5$ & 5 \\
\hline S. dysenteriae & $5.66 \pm 0.54$ & $9.10 \pm 1.26$ & $5.5 \pm 0.81$ & 1.25 \\
\hline S. aureus & $10.66 \pm 0.60$ & $12 \pm 0$ & $9.75 \pm 0.4$ & 0.75 \\
\hline E. coli & $6 \pm 0$ & $8.33 \pm 0.87$ & $5.25 \pm 0.64$ & 1.25 \\
\hline L. monocytogenes & $5 \pm 0$ & $6.58 \pm 2.02$ & $4 \pm 0$ & 2.5 \\
\hline S. typhimurium & $4.5 \pm 3.39$ & $5 \pm 0$ & $3 \pm 0$ & 5 \\
\hline $\begin{array}{l}\text { B. animalis sbsp } \\
\text { lactis }\end{array}$ & - & - & - & - \\
\hline Lb. rhamnosus & - & - & - & - \\
\hline
\end{tabular}

According to the results, the second stage of maturation had a higher antibacterial activity, followed by the first and third stages. This could be explained by the phenolic content of each stage as the second stage had the highest total phenolics and flavonoids. The response of the strains to the same sample also varies.

It was also observed that gram-negative bacteria were more resistant to pumpkin polyphenols than gram-positive strains. In gram-positive bacteria, there is a thick layer of peptidoglycan that protects a single bilayer. On the other hand, the cell envelope of gram-negative bacteria consists of a thin layer of peptidoglycan surroundedbyanouter lipopolysaccharidemembrane [72]. Gram-negative bacteria have an extra layer playing an essential role in protecting from the hostile environment by excluding toxic molecules without compromising the exchange of material needed for sustaining life [73].

Staphylococcus aureus was the most sensitive strain to Cucurbita phenolic extract with an inhibition zone of $12 \mathrm{~mm}$ and a MIC of $0.75 \mathrm{mg} \mathrm{L}^{-1}$. The lowest inhibition zones were obtained with Salmonella typhimurium $(5 \mathrm{~mm})$. This resistance was also observed with the MIC value $\left(10 \mathrm{mg} \mathrm{L}^{-1}\right)$.

The major polyphenols identified in pumpkins belong to the phenolic acid class. Phenolic acids appeared to exhibit more significant antimicrobial activity than flavonoids. Thus, microbial transformations of some flavonoids could lead to more powerful compounds with a more significant antimicrobial effect (phenolic acids) that selectively affect intestinal bacteria [74-78]. Gallic acid, caffeic acid, and ferulic acid had better antimicrobial activity against Gram-positive and Gram-negative bacteria than gentamicin and streptomycin [79].

Polyphenolic compounds are excellent natural antimicrobial agents. Although the exact mechanism responsible for the antibacterial activity is still not well understood, several possible action mechanisms were described. For example, polyphenols might induce cell wall damage resulting in leakage of intracellular components such as ions, ATP, nucleic acids, and amino acids. Moreover, cell damage may also be related to nutrient uptake, inhibiting DNA synthesis by suppressing gyrase activity, influencing protein biosynthesis, blocking ATP synthesis, reducing the $\mathrm{pH}$ level inside the bacterial cell, and affecting biofilm formation [80-83].

Both beneficial strains Bifidobacterium animalis sbsp lactis (Bb12) and Lactobacillus rhamnosus LbRE-LSAS were resistant to polyphenol extracts. Prior studies have demonstrated that phenolic compounds have a selective effect, as they inhibit the growth of pathogens and stimulate commensal bacteria and probiotics, including Lactobacillus and Bifidobac- 
terium species. Polyphenols tend to provide health benefits by exerting prebiotic-like effects and modulating the gut microbiota $[84,85]$. The potential prebiotic effects of food polyphenols are associated with the ability of intestinal microbiota to convert phenolics into their metabolites, which in turn contribute to modulate intestinal microbiota [86,87].

The antimicrobial activity of plant extracts has been demonstrated mainly in vitro. Nevertheless, some aspects are crucial for its use in foods. The activity of these compounds in bothinvitroand on the foodstuffs once applied tests are different; this could be explained by the presence of fat, carbohydrate, protein, salt, and $\mathrm{pH}$, which may influence the effectiveness of these agents in foods [88-91]. Moreover, the availability of nutrients in food preparations compared with the culture media may enable the fast repair of damaged cells by the respective bacteria. Besides that, high levels of fat and/or protein in the foodstuffs might protect bacteria from the action of these natural extracts [89]. Storage temperature may also influence the effectiveness of antimicrobials as the diffusibility of compounds is related to the temperature [92,93]. Finally, and most importantly, we have to consider the effects of the extract on the sensory characteristics of the food products and make sure that the use of these natural preservatives cannot alter the organoleptic properties of food $[91,93]$.

\section{Material and Methods}

\subsection{Plant Material}

The fruits of pumpkin were collected at three different development stages (i.e., young, mature, and ripened) from the region of Mostaganem (Algeria) during May 2018. Three fruit samples from each stage of development were selected based on their morphological attributes such as size, weight, and color. Fruits were washed, air-dried and the physical parameters were recorded.

\subsection{Polyphenol Extraction}

The extraction was carried out using the method of Mokhtar et al. [27]. A sample of $200 \mathrm{~g}$ of each stage had undergone two successive extractions, the first one using methanol as a solvent and the second one with ethyl acetate $(0.05 \% v / v$ hydrochloric acid/solvent (10:90)) under sonication for 30min. Both extracts were combined, filtered, and evaporated until dry. The entire process is conducted in darkness and repeated in triplicate.

\subsection{Phytochemical Investigations}

\subsubsection{Determination of Total Phenolics}

The Folin-Ciocalteau reagent method is used to determine total polyphenols [94]. A sample of $100 \mu \mathrm{L}$ of each extract is added to $4.9 \mathrm{~mL}$ of distilled water in a $10 \mathrm{~mL}$ volumetric flask. Folin-Ciocalteau's phenol reagent $(0.5 \mathrm{~mL} ; 2 \mathrm{~N})$ is mixed with the solution. Three minutes later, $1 \mathrm{~mL}$ of a saturated sodium carbonate solution $(35 \% w / v)$ is added into the mixture, following by topping it up to $10 \mathrm{~mL}$ with water. After $30 \mathrm{~min}$ of incubation, the absorbance is measured at $725 \mathrm{~nm}$ using a spectrophotometer. The content is expressed as $\mathrm{mg}$ of gallic acid equivalents/100 $\mathrm{g}$ of fruit.

\subsubsection{Determination of Total Flavonoids}

Total flavonoids of pumpkins were determined according to the method of Pothirat et al. [95]. A sample of $500 \mu \mathrm{L}$ of the extracts collected at three stages of ripeness is mixed with the same amount of $2 \%$ aluminum chloride solution. After 10 min of reaction, the absorbance is measured at $415 \mathrm{~nm}$ against a blank that contains the sample without aluminum chloride. The results are expressed as $\mathrm{mg}$ of quercetin equivalents $/ 100 \mathrm{~g}$ of fruit.

\subsubsection{Identification of Phenolic Compounds by HPLC-DAD-ESI-MS}

The chromatographic analyses were performed using a Thermo Finnigan Surveyor Plus HPLC apparatus consisting of a quaternary pump, a Surveyor UV-Vis photodiode 
array (PDA) detector, and LCQ Advantage max ion trap mass spectrometer (Thermo Fisher Scientific, Waltham, MA, USA), coupled through an electrospray ionization (ESI) source.

The separation was conducted on a Gemini C18 $110 \AA(150 \times 2 \mathrm{~mm}, 5 \mu \mathrm{m})$. Water (A) and methanol (B) were used as mobile phases; both were acidified with $0.075 \%$ of formic acid. The gradient elution was as follows: $0-5 \mathrm{~min}$ : $2 \%$ of B, 5-120 min: $2-100 \%$ of $\mathrm{B}$. The flow rate was $1 \mathrm{~mL} / \mathrm{min}$, and the injection volume was $2 \mu \mathrm{L}$ [27]. Spectral data were collected in the range of $200-800 \mathrm{~nm}$ for all peaks, and the chromatograms were recorded at $\lambda=280 \mathrm{~nm}$. HPLC-ESI-MS/MS data were obtainedinbothpositive and negative ionization modes. The external standard method was used to quantify each compound, and the results were expressed as $\mu \mathrm{g} \mathrm{g}^{-1}$ fresh weight $\pm \mathrm{SD}$.

\subsection{Antioxidant Activity Measurement}

A wide range of spectrophotometric assays has been used in recent years to measure the antioxidant capacity of foods and biological samples. Among the most frequently used methods for determining antioxidant capacity are the ABTS and DPPH assays [50,51].

\subsubsection{DPPH Test}

The free radical-scavenging capacity of Cucurbita polyphenols is tested as bleaching of the stable radical DPPH. The DPPH assay is done according to the method of Siracusa et al. [96]. DPPH• has a maximum absorbance at $517 \mathrm{~nm}$; its deep violet color becomes colorless when converted into DPPH-H. A volume of $37.5 \mu \mathrm{L}$ of the tested samples is added to $1.5 \mathrm{~mL}$ of DPPH $(0.1 \mathrm{mmol})$. After an incubation time of $20 \mathrm{~min}$, the absorbance is measured at $517 \mathrm{~nm}$. Trolox is used as the standard, and the tested sample is replaced by methanol for the control. The concentrations are reported as $\mu \mathrm{mol} \mathrm{TE} / \mathrm{g}$ ( $\mathrm{TE}=\mathrm{Trolox}$ Equivalent/g of extract).

\subsubsection{Trolox Equivalent Antioxidant Capacity (TEAC)}

The ABTS solution [2,2-azinobis-(3-ethylbenzothiazoline-6-sulfonic acid)] is prepared 12 to 14 hours earlier and is kept in darkness by mixing $1.7 \mathrm{mmol} \mathrm{L}^{-1}$ of ABTS to $4.3 \mathrm{mmol} . \mathrm{L}^{-1}$ of potassium peroxydisulfate in water in the ratio of 5:1. The concentrated $\mathrm{ABTS}^{\bullet}$ solution is diluted with methanol to reach a final absorbance of $0.70 \pm 0.02$ at $734 \mathrm{~nm}$. Next, a stock solution of Trolox is prepared in methanol at different concentrations ranging between 0 and $250 \mathrm{mmol}$. A volume of $0.1 \mathrm{~mL}$ (tested sample/ standard/methanol for the control) is added to $2 \mathrm{~mL}$ of ABTS• solution, and the absorbance is measured at $734 \mathrm{~nm}$ after $6 \mathrm{~min}$ against a blank. The TEAC of different stages of Cucurbita polyphenols is calculated by relating this decrease in absorbance to that of a Trolox solution on a molar basis [97].

\subsection{Antimicrobial Activity}

\subsubsection{Microbial Strains}

Staphylococcus aureus ATCC 6538,Listeria monocytogenes ATCC 7644, Escherichia coli ATCC 10536; Salmonella typhimurium ATCC 13311,Enterococcus hirae ATCC 10541, Proteus mirabilis ATCC 13315, Bacillus subtilis ATCC 6633, Shigella dysenteriae CECT 457, Pseudomonas aeruginosa ATCC 27853, Bifidobacterium animalis sbsp lactis (Bb12), and Lactobacillus rhamnosus LbRE-LSAS were obtained from the LMBAF laboratory (University of Mostaganem, Mostaganem, Algeria).

\subsubsection{Antimicrobial Screening}

The antimicrobial activity of the pumpkin polyphenols is determined according to the agar disc diffusion method. Bacterial inocula are prepared 16h earlier in Muller-Hinton broth (MHB, Oxoid) at $37^{\circ} \mathrm{C}$, and adjusted to $10^{8} \mathrm{CFU} / \mathrm{mL}$ prior to use. A volume of $20 \mu \mathrm{L}$ of each stage is deposited on sterile filter paper disks $(6 \mathrm{~mm})$. Another disk containing DMSO is also placed on the plate as a negative control. To ensure compound diffusion, the plates are left for $30 \mathrm{~min}$ at room temperature and then incubated at $37^{\circ} \mathrm{C}$. After $24 \mathrm{~h}$, the inhibition zone diameter is measured [98]. 
The pumpkin stage with the best inhibition zones is selected to determine the minimum inhibitory concentration (MIC) by the broth microdilution method [98]. Bacterial suspension of $100 \mu \mathrm{L}$ is added to the wells of a sterile 96-well microtiter plate already containing $100 \mu \mathrm{L}$ of the diluted tested samples and incubated for $24 \mathrm{~h}$ at $37^{\circ} \mathrm{C}$. The final concentration of the inoculum was approximately $5 \times 10^{5} \mathrm{CFU} / \mathrm{mL}$.

\subsection{Statistical Analysis}

The statistical analysis is performed using Statbox pro (6.40). Each experiment was repeated three times, and the results are expressed as means \pm SD.Differences between the means are evaluated using one-way ANOVA, and is considered significant at $p \leq 0.05$.

\section{Conclusions}

Pumpkin is a valuable source of bioactive compounds responsible for several biological activities. The current research is a preliminary study that focused on the development of the phenolic profile of Cucurbita moschata during different maturation stages and their antioxidant and antimicrobial activities. Among the three stages, high levels of polyphenols were determined in the mature fruits. After the analysis with HPLC-DAD-ESI-MS, 33 compounds were identified, and syringic acid was the most important. Polyphenol extract of the mature fruits showed the highest antioxidant and antimicrobial activities, which can be attributed to high levels of phenolic acids and flavonoids. The obtained results in the present work contribute to highlight that pumpkins may be considered useful as a food preservative. However, further studies should be conducted to study the effectiveness of pumpkin polyphenols as a natural preservative in a food model.

Author Contributions: Conceptualization, M.M., A.R. and M.D.; methodology, M.M., S.B., A.D.L., C.T.; software, M.M.; validation, M.D., A.R. and M.M.; formal analysis, M.D.; investigation, S.B., M.M.; resources, A.R., M.D.; data curation, M.M., A.R and M.D.; writing—original draft preparation, M.M.; writing—review and editing, M.M., A.R. and M.D.; visualization, S.B., M.M.; supervision, A.R. and M.D.; project administration, A.R. and M.D.; funding acquisition, A.R. and M.D. All authors have read and agreed to the published version of the manuscript.

Funding: This research was funded by the Ministry of Higher Education and Scientific Research, University of Abdelhamid Ibn Badis, (Mostaganem, Algeria), and the University of Pavia (Pavia, Italy).

Institutional Review Board Statement: Not applicable.

Informed Consent Statement: Not applicable.

Data Availability Statement: Not applicable.

Acknowledgments: Authors would like to thank the Department of Drug Sciences, Medicinal Chemistry and Pharmaceutical Technology, University of Pavia for conducting a part of the works in their laboratories.

Conflicts of Interest: The authors declare that they have no conflict of interest.

Sample Availability: Samples of the pumpkins are available from the authors.

\section{References}

1. Saini, R.K.; Rengasamy, K.R.R.; Mahomoodally, F.M.; Keum, Y.S. Protective effects of lycopene in cancer, cardiovascular, and neurodegenerative diseases: An update on epidemiological and mechanistic perspectives. Pharmacol. Res. 2020, 155, 104730. [CrossRef]

2. Sharifi-Rad, J.; Rodrigues, C.F.; Sharopov, F.; Docea, A.O.; Can Karaca, A.; Sharifi-Rad, M.; KahveciKarıncaoglu, D.; Gülseren, G.; Şenol, E.; Demircan, E.; et al. Diet, Lifestyle and Cardiovascular Diseases: Linking Pathophysiology to Cardioprotective Effects of Natural Bioactive Compounds. Int. J. Environ. Res. Public Health 2020, 17, 2326. [CrossRef]

3. Arfaoui, L. Dietary Plant Polyphenols: Effects of Food Processing on Their Content and Bioavailability. Molecules 2021, 26, 2959. [CrossRef]

4. Wang, Y.; Gallegos, J.L.; Haskell-Ramsay, C.; Lodge, J.K. Effects of chronic consumption of specific fruit (berries, citrus and cherries) on CVD risk factors: A systematic review and meta-analysis of randomised controlled trials. Eur. J. Nutr. 2021, 60, 615-639. [CrossRef] [PubMed] 
5. Alzobaidi, N.; Quasimi, H.; Emad, N.A.; Alhalmi, A.; Naqvi, M. Bioactive Compounds and Traditional Herbal Medicine: Promising Approaches for the Treatment of Dementia. Degener Neurol. Neuromuscul. Dis. 2021, 11, 1-14. [PubMed]

6. Kamala Kumari, P.V.; Akhila, S.; Srinivasa Rao, Y.; Rama Devi, B. Alternative to artificial preservatives. Syst. Rev. Pharm. 2019, 10, 13-16.

7. Mokhtar, M.; Russo, M.; Cacciola, F.; Donato, P.; Giuffrida, D.; Riazi, A.; Farnetti, S.; Dugo, D.; Mondello, L. Capsaicinoids and Carotenoids in Capsicum annuum L.: Optimization of the Extraction Method, Analytical Characterization, and Evaluation of its Biological Properties. Food Anal. Methods 2016, 9, 1381-1390. [CrossRef]

8. Kourkoutas, Y.; Proestos, C. Food Preservation: Challenges and Efforts for the Future. Foods 2020, 9, 391. [CrossRef]

9. Bom, S.; Fitas, M.; Martins, A.M.; Pinto, P.; Ribeiro, H.M.; Marto, J. Replacing Synthetic Ingredients by Sustainable Natural Alternatives: A Case Study Using Topical O/W Emulsions. Molecules 2020, 25, 4887. [CrossRef]

10. Murkovic, M.; Mülleder, U.; Neunteufl, H. Carotenoid content in different varieties of pumpkins. J. Food. Compost. Anal. 2002, 15, 633-638. [CrossRef]

11. Kulczyński, B.; Gramza-Michałowska, A. The Profile of Secondary Metabolites and Other Bioactive Compounds in Cucurbita pepo L. and Cucurbita moschata Pumpkin Cultivars. Molecules 2019, 24, 2945. [CrossRef]

12. Pinho, F.G.R.; Henrriques, F.; Barroca, M.J. Mass transfer coefficients for the drying of pumpkin (Cucurbita moschata) and dried product quality. Food Bioprocess. Technol. 2012, 5, 176-183.

13. Conti, S.; Villari, G.; Amico, E.; Caruso, G. Effects of production system and transplanting time on yield, quality and antioxidant content of organic winter squash (Cucurbita moschata Duch.). Sci. Hortic. 2015, 183, 136-143. [CrossRef]

14. Men, X.; Choi, S.I.; Han, X.; Kwon, H.Y.; Jang, G.W.; Choi, Y.E.; Park, S.M.; Lee, O.H. Physicochemical, nutritional and functional properties of Cucurbita moschata. Food Sci. Biotechnol. 2020, 30, 171-183. [CrossRef] [PubMed]

15. Magdeleine, C.M.; Mahieu, M.; Archimede, H. Pumpkin (Cucurbita moschata Duchesne ex Poir.) Seeds as an Anthelmintic Agent. In Nuts and Seeds in Health and Disease Prevention, 1st ed.; Preedy, V., Watson, R., Patel, V., Eds.; Elsevier: Amsterdam, The Netherlands, 2011; pp. 933-939.

16. Jiang, Z.; Du, Q. Glucose-lowering activity of novel tetrasaccharideglyceroglycolipids from the fruits of Cucurbita moschata. Bioorg. Med. Chem. Lett. 2011, 21, 1001-1003. [CrossRef] [PubMed]

17. Zhang, B.; Huang, H.; Xie, J.; Xu, C.; Chen, M.; Wang, C.; Yang, A.; Yin, Q. Cucurmosin induces apoptosis of BxPC-3 human pancreatic cancer cells via inactivation of the EGFR signaling pathway. Oncol. Rep. 2012, 27, 891-897. [PubMed]

18. García-Parra, J.; Gonzâlez-Cebrino, F.; Delgado, J.; Cava, R.; Ramírez, R. High pressure assisted thermal processing of pumpkin puree: Effect on microbial counts, color, bioactive compounds and polyphenol oxidase enzyme. Food Bioprod. Process. 2016, 98, 124-132. [CrossRef]

19. Alhakamy, N.A.; Fahmy, U.A.; Ahmed, O. Attenuation of Benign Prostatic Hyperplasia by Optimized Tadalafil Loaded Pumpkin Seed Oil-Based Self Nanoemulsion: In Vitro and In Vivo Evaluation. Pharmaceutics 2019, 11, 640. [CrossRef] [PubMed]

20. Bouamar, S.; Mokhtar, M.; Bouziane, N.; Boukazzoula, K.; Riazi, A. Anti-inflammatory properties of the carotenoids and polyphenols of pumpkin (Cucurbita moschata Duchesne). South. Asian J. Exp. Biol. 2017, 7, 100-106.

21. Kim, K.; Choi, J.-H.; Oh, J.; Park, J.-Y.; Kim, Y.-M.; Moon, J.-H.; Park, J.-H.; Cho, J.-Y. New 8-C-p-Hydroxylbenzylflavonol Glycosides from Pumpkin (Cucurbita moschata Duch.) Tendril and Their Osteoclast Differentiation Inhibitory Activities. Molecules 2020, 25, 2077. [CrossRef]

22. Dong, X.J.; Chen, J.Y.; Chen, S.F.; Li, Y.; Zhao, X.J. The composition and anti-inflammatory properties of pumpkin seeds. Food Meas. 2021, 15, 1834-1842. [CrossRef]

23. Dragovic-Uzelac, V.; Delonga, K.; Levaj, B.; Djakovic, S.; Pospisil, J. Phenolic profiles of raw apricots, pumpkins, and their purées in the evaluation of apricot nectar and jam authenticity. J. Agric. Food Chem. 2005, 53, 4836-4842. [CrossRef]

24. Huang, H.X.; Yu, T.; Li, J.X.; Qu, S.P.; Wang, M.M.; Wu, T.Q.; Zhong, Y.J. Characterization of Cucurbita maxima fruit Metabolomic profiling and transcriptome to reveal fruit quality and ripening gene expression patterns. J. Plant Biol. 2019, 62, 203-216. [CrossRef]

25. Jaffery, E.H.; Brown, A.F.; Kurilich, A.C.; Keek, A.S.; Matusheski, N.; Klein, B.P. Variation in content of bioactive components in broccoli. J. Food Composit. Anal. 2003, 16, 323-330. [CrossRef]

26. Siddiqui, M.W.; Momin, C.M.; Acharya, P.; Kabir, J.; Debnath, M.K.; Dihua, R.S. Dynamics of changes in bioactive molecules and antioxidant potential of Capsicum chinense Jacq. cv. Habanero at nine maturity stages. Acta Physiol. Plant 2013, 35, 1141-1148. [CrossRef]

27. Mokhtar, M.; Soukup, J.; Donato, P.; Cacciola, F.; Dugo, P.; Riazi, A.; Jandera, P.; Mondello, L. Determination of the polyphenolic content of Capsicum annuum L. by liquid chromatography coupled to photodiode array and mass spectrometry detection and evaluation of its biological activity. J. Sep. Sci. 2015, 38, 171-178. [CrossRef] [PubMed]

28. Handa, A.K.; Tiznando-Hernandez, M.E.; Mattoo, A.K. Fruit development and ripening: A molecular perspective. Plant. Biotechnol. Agric. 2012, 405-424.

29. Tiwari, U.; Cummins, E. Factors influencing levels of phytochemicals in selected fruit and vegetables during pre- and post-harvest food processing operations. Food Res. Int. 2013, 50, 497-506. [CrossRef]

30. Kulkarni, A.P.; Aradhya, S.M. Chemical Changes and Antioxidant Activity in Pomegranate Arils during Fruit Development. Food Chem. 2005, 93, 319-324. [CrossRef]

31. Fawole, O.A.; Opara, U.L. Developmental Changes in Maturity Indices of Pomegranate Fruit: A Descriptive Review. Sci. Hortic. 2013, 159, 152-161. [CrossRef] 
32. Oloyede, F.M.; Agbaje, G.O.; Obuotor, E.M.; Obisesan, I.O. Nutritional and antioxidant profiles of pumpkin (Cucurbita pepo Linn.) immature and mature fruits as influenced by NPK fertilizer. Food Chem. 2012, 135, 460-463. [CrossRef]

33. Zdunic, G.M.; Menkovic, N.R.; Jadranin, M.B.; Novakovic, M.M.; Savikin, K.P.; Zivkovic, J.C. Phenolic compounds and carotenoids in pumpkin fruit and related traditional products. Hem. Ind. 2016, 70, 429-433. [CrossRef]

34. Speirs, J.; Brady, C.J. Modification of gene expression in ripening fruit. Aust. J. Plant Physiol. 1991, 18, 519-532. [CrossRef]

35. Dragovic-Uzelac, V.; Levaj, B.; Mrkic, V.; Bursac, D.; Boras, M. The Content of Polyphenols and Carotenoids in Three Apricot Cultivars Depending on Stage of Maturity and Geographical Region. Food Chem. 2007, 102, 966-975. [CrossRef]

36. Robbins, R.J. Phenolic acids in foods: An overview of analytical methodology. J. Agric. Food Chem. 2003, 51, 2866-2887. [CrossRef] [PubMed]

37. Pericin, D.; Krimer, V.; Trivic, S.; Radulovic, L. The distribution of phenolic acids in pumpkin's hull-less seed, skin, oil cake meal, dehulled kernel and hull. Food Chem. 2009, 113, 450-456. [CrossRef]

38. Ko, J.; Ko, M.; Kim, D.; Lim, S. Enhanced production of phenolic compounds from pumpkin leaves by subcritical water hydrolysis. Prev. Nutr. Food Sci. 2016, 21, 132. [CrossRef] [PubMed]

39. Abu-Reidah, I.M.; Arráez-Román, D.; Quirantes-Piné, R.; Fernández-Arroyo, S.; Segura-Carretero, A.; Fernández-Gutiérrez, A. HPLC-ESI-Q-TOF-MS for a comprehensive characterization of bioactive phenolic compounds in cucumber whole fruit extract. Food Res. Int. 2012, 46, 108-117. [CrossRef]

40. Sicilia, T.; Niemeyer, H.B.; Honig, D.M.; Metzler, M. Identification and stereochemical characterization of lignans in flaxseed and pumpkin seeds. J. Agric. Food Chem. 2003, 51, 1181-1188. [CrossRef]

41. Ghisoni, S.; Chiodelli, G.; Rocchetti, G.; Kane, D.; Lucin, L. UHPLC-ESI-QTOF-MS screening of lignans and other phenolics in dry seeds for human consumption. J. Funct. Foods 2017, 34, 229-236. [CrossRef]

42. Iswaldi, I.; Gomez-Caravaca, A.M.; Lozano-Sanchez, J.; Arraez-Roman, D.; Segura-Carretero, A.; Fernandez-Gutierrez, A. Profiling of phenolic and other polar compounds in zucchini (Cucurbita pepo L.) by reverse-phase high-performance liquid chromatography coupled to quadrupole time-of-flight mass spectrometry. Food Res. Int. 2013, 50, 77-84. [CrossRef]

43. Wang, S.Y.; Zheng, W. Effect of plant growth temperature on antioxidant capacity in strawberry. J. Agric. Food Chem. 2001, 49, 4977-4982. [CrossRef] [PubMed]

44. Ayala-Zavala, J.F.; Wang, S.Y.; Wang, C.Y.; Gonzalez-Aguilar, G.A. Effect of storage temperatures on antioxidant capacity and aroma compounds in strawberry fruit. LWT Food Sci. Technol. 2004, 37, 687-695. [CrossRef]

45. Serrano, M.; Guillen, F.; Martinez-Romero, D.; Castillo, S.; Valero, D. Chemical constituents and antioxidant activity of sweet cherry at different ripening stages. J. Agric. Food Chem. 2005, 53, 2741-2745. [CrossRef]

46. Yang, J.; Gadi, R.; Thomson, T. Antioxidant capacity, total phenols, and ascorbic acid content of noni (Morindacitrifolia) fruits and leaves at various stages of maturity. Micronesica 2011, 41, 167-176.

47. Ndri, D.; Calani, L.; Mazzeo, T.; Scazzina, F.; Rinaldi, M.; Rio, D.D.; Pellegrini, N.; Brighenti, F. Effects of different maturity stages on antioxidant content of Ivorian Gnagnan (Solanum indicum L.) berries. Molecules 2010, 15, 7125-7138. [CrossRef] [PubMed]

48. Gundogdu, M.; Kan, T.; Gecer, M.K. Vitamins, flavonoids, and phenolic acid levels in early and late ripening apricot (Prunus armeniaca L.) Cultivars from Turkey. Hort. Sci. 2013, 48, 696-700.

49. Molyneux, P. The use of the stable free radical diphenylpicryl-hydrazyl (DPPH) for estimating antioxidant activity. Songklanakarin J. Sci. Technol. 2004, 26, 211-219.

50. Thaipong, K.; Boonprakob, U.; Crosby, K.; Cisneros-Zevallos, L.; Hawkins Byrne, D. Comparison of ABTS, DPPH, FRAP, and ORAC assays for estimating antioxidant activity from guava fruit extracts. J. Food Compost Anal. 2006, 19, 669-675. [CrossRef]

51. Floegel, A.; Kim, D.O.; Chung, S.J.; Song, W.O.; Fernandez, M.L.; Bruno, R.S.; Koo, S.I.; Chun, O.K. Development and validation of an algorithm to establish a total antioxidant capacity database of the US diet. Int. J. Food Sci. Nutr. 2010, 61, 600-623. [CrossRef] [PubMed]

52. Fischer, U.A.; Carle, R.; Kammerer, D.R. Identification and quantification of phenolic compounds from pomegranate (Punicagranatum L.) peel, mesocarp, aril and differently produced juices by HPLC-DAD-ESI/MS. Food Chem. 2011, 127, 807-821. [CrossRef] [PubMed]

53. Gil, M.I.; Tomas-Barberan, F.A.; Hess-Pierce, B.; Holcroft, D.M.; Kader, A.A. Antioxidant activity of pomegranate juice and its relationship with phenolic composition and processing. J. Agric. Food Chem. 2000, 48, 4581-4589. [CrossRef] [PubMed]

54. Aryal, S.; Baniya, M.K.; Danekhu, K.; Kunwar, P.; Gurung, R.; Koirala, N. Total Phenolic Content, Flavonoid Content and Antioxidant Potential of Wild Vegetables from Western Nepal. Plants 2019, 8, 96. [CrossRef]

55. Srinivasulu, C.; Ramgopal, M.; Ramanjaneyulu, G.; Anuradha, C.M.; Suresh Kumar, C. Syringic acid (SA): A Review of Its Occurrence, Biosynthesis, Pharmacological and Industrial Importance. Biomed. Pharmacother. 2018, 108, 547. [CrossRef]

56. Vo, Q.V.; Bay, M.V.; Nam, P.C.; Quang, D.T.; Flavel, M.; Hoa, N.T.; Mechler, A. Theoretical and Experimental Studies of the Antioxidant and Antinitrosant Activity of Syringic Acid. J. Org. Chem. 2020, 85, 15514-15520. [CrossRef] [PubMed]

57. Cikman, O.; Soylemez, O.; Ozkan, O.F.; Kiraz, H.A.; Sayar, I.; Ademoglu, S.; Taysi, S.; Karaayvaz, M. Antioxidant Activity of Syringic Acid Prevents Oxidative Stress in L-arginine-Induced Acute Pancreatitis: An Experimental Study on Rats. Int. Surg. 2015, 100, 891. [CrossRef] [PubMed]

58. Arumugam, B.; Balagangadharan, K.; Selvamurugan, N. Syringic Acid, a Phenolic Acid, Promotes Osteoblast Differentiation by Stimulation of Runx2 Expression and Targeting of Smad7 by Mir-21 in Mouse Mesenchymal Stem Cells. Cell Commun. Sign. 2018, 12, 561. [CrossRef] 
59. Ji, J.; Yang, X.; Flavel, M.; Shields, Z.P.-I.; Kitchen, B. Antioxidant and Anti-Diabetic Functions of a Polyphenol-Rich Sugarcane Extract. J. Am. Coll. Nutr. 2019, 38, 670. [CrossRef]

60. Rashedinia, M.; Sabahi, Z.; Khoshnoud, M.J.; Khalvati, B.; Hashemi, S.-S.; Farsani, Z.G.; Gerashi, H.M. Syringic Acid Improves Oxidative Stress and Mitochondrial Biogenesis in the Liver of Streptozotocin-Induced Diabetic Rats. Asian Pac. J. Trop. Biomed. 2020, 10, 111. [CrossRef]

61. Chandra, S.; Roy, A.; Jana, M.; Pahan, K. Cinnamic Acid Activates PPAR $\alpha$ to Stimulate Lysosomal Biogenesis and Lower Amyloid Plaque Pathology in an Alzheimer's Disease Mouse Model. Neurobiol. Dis. 2019, 124, 379-395. [CrossRef]

62. Ruwizhi, N.; Aderibigbe, B.A. Cinnamic Acid Derivatives and Their Biological Efficacy. Int. J. Mol. Sci. 2020, 21, 5712. [CrossRef]

63. Abd El-Raouf, O.M.; El-Sayed, M.; Manie, M.F. Cinnamic Acid and Cinnamaldehyde Ameliorate Cisplatin-Induced Splenotoxicity in Rats. J. Biochem. Mol. Toxicol. 2015, 29, 1-6. [CrossRef] [PubMed]

64. Wang, R.; Yang, W.; Fan, Y.; Dehaen, W.; Li, Y.; Li, H.; Wang, W.; Zheng, Q.; Huai, Q. Design and Synthesis of the Novel Oleanolic Acid-Cinnamic Acid Ester Derivatives and Glycyrrhetinic Acid-Cinnamic Acid Ester Derivatives with Cytotoxic Properties. Bioorg. Chem. 2019, 88, 102951. [CrossRef] [PubMed]

65. Guo, S.; Zhen, Y.; Zhu, Z.; Zhou, G.; Zheng, X. Cinnamic Acid Rescues Behavioral Deficits in a Mouse Model of Traumatic Brain Injury by Targeting MiR-455-3p/HDAC. Life Sci. 2019, 235, 116819. [CrossRef] [PubMed]

66. Zhang, W.X.; Wang, H.; Cui, H.R.; Guo, W.B.; Zhou, F.; Cai, D.S.; Xu, B.; Jia, X.H.; Huang, X.M.; Yang, Y.Q. Design, Synthesis and Biological Evaluation of Cinnamic Acid Derivatives with Synergetic Neuroprotection and Angiogenesis Effect. Eur. J. Med. Chem. 2019, 183, 1-16. [CrossRef]

67. De Lima, G.D.A.; Rodrigues, M.P.; de Mendes, T.A.O.; Moreira, G.A.; Siqueira, R.P.; da Silva, A.M.; Vaz, B.G.; Fietto, J.L.R.; Bressan, G.C.; Machado-Neves, M. Synthesis and Antimetastatic Activity Evaluation of Cinnamic Acid Derivatives Containing 1,2,3-Triazolic Portions. Toxicol. In Vitro 2018, 53, 1-9. [CrossRef] [PubMed]

68. Ugazio, E.; Carlotti, M.E.; Sapino, S.; Trotta, M.; Vione, D.; Minero, C. Photodegradation of Cinnamic Acid in Different Media. J. Dispers. Sci. Technol. 2008, 29, 641-652. [CrossRef]

69. Jakovljević, K.; Joksović, M.D.; Botta, B.; Jovanović, L.S.; Avdović, E.; Marković, Z.; Marković, V. Novel 1,3,4-thiadiazole conjugates derived from protocatechuic acid: Synthesis, antioxidant activity, and computational and electrochemical studies. C. R. Chim. 2019, 22, 585-598. [CrossRef]

70. El-Sonbaty, Y.A.; Suddek, G.M.; Megahed, N.; Gameil, N.M. Protocatechuic acid exhibits hepatoprotective, vasculoprotective, antioxidant and insulin-like effects in dexamethasone-induced insulin-resistant rats. Biochimie 2019, 167, 119-134. [CrossRef]

71. Mandalari, G.; Bisignano, C.; D’Arrigo, M.; Ginestra, G.; Arena, A.; Tomaino, A.; Wickham, M.S.J. Antimicrobial potential of polyphenols extracted from almond skins. Lett. Appl. Microbiol. 2010, 51, 83-89. [CrossRef]

72. Furse, S.; Scott, D.J. Three-Dimensional Distribution of Phospholipids in Gram Negative Bacteria. Biochemistry 2016, 55, 4742-4747. [CrossRef]

73. Delcour, A.H. Outer Membrane Permeability and Antibiotic Resistance. Biochim. Biophys. Acta Proteins Proteomics 2009, 1794, 808-816. [CrossRef]

74. Cueva, C.; Moreno-Arribas, M.V.; Martinez-Alvarez, P.J.; Bills, G.; Vicente, M.F.; Basilio, A.; Lopez Rivas, C.; Requena, T. Antimicrobial activity of phenolic acids against commensal, probiotic and pathogenic bacteria. Res. Microbiol. 2010, 16, 372-382. [CrossRef]

75. Mokhtar, M.; Ginestra, G.; Youcefi, F.; Filocamo, A.; Bisignano, C.; Riazi, A. Antimicrobial activity of selected polyphenols and capsaicinoids identified in pepper (Capsicum annuum L.) and their possible mode of interaction. Curr. Microbiol. 2017, 74, 1253-1260. [CrossRef]

76. Daglia, M. Polyphenols as antimicrobial agents. Curr. Opin. Biotechnol. 2012, 23, 174-181. [CrossRef] [PubMed]

77. Shirai, A.; Yasutomo, Y.K. Bactericidal action of ferulic acid with ultraviolet-A light irradiation. J. Photochem.Photobiol. B Biol. 2019, 191, 52-58. [CrossRef]

78. Oliveira, E.F.; Yang, X.; Basnayake, N.; Huu, C.N.; Wang, L.; Tikekar, R.V.; Nitin, N. Screening of antimicrobial synergism between phenolic acids derivatives and UV-A light radiation. J. Photochem. Photobiol. B. 2021, 214, 112081. [CrossRef] [PubMed]

79. Saavedra, M.J.; Borges, A.; Dias, C.; Aires, A.; Bennett, R.; Rosa, E.S.; Simoes, M. Antimicrobial activity of phenolics and glucosinolate hydrolysis products and their synergy with streptomycin against pathogenic bacteria. J. Med. Chem. 2010, 6, 174-183. [CrossRef] [PubMed]

80. Bhattacharya, D.; Ghosh, D.; Bhattacharya, S.; Sarkar, S.; Karmakar, P.; Koley, H.; Gachhui, R. Antibacterial activity of polyphenolic fraction of Kombucha against Vibrio cholerae: Targeting cell membrane. Lett. Appl. Microbiol. 2018, 66, 145-152. [CrossRef] [PubMed]

81. Gorzynik-Debicka, M.; Przychodzen, P.; Cappello, F.; Kuban-Jankowska, A.; Marino Gammazza, A.; Knap, N.; Wozniak, M.; Gorska-Ponikowska, M. Potential Health Benefits of Olive Oil and Plant Polyphenols. Int. J. Mol. Sci. 2018, 19, 686. [CrossRef]

82. Cory, H.; Passarelli, S.; Szeto, J.; Tamez, M.; Mattei, J. The Role of Polyphenols in Human Health and Food Systems: A Mini-Review. Front. Nutr. 2018, 5, 87. [CrossRef]

83. Efenberger-Szmechtyk, M.; Nowak, A.; Czyzowska, A. Plant extracts rich in polyphenols: Antibacterial agents and natural preservatives for meat and meat products. Crit. Rev. Food Sci. Nutr. 2020, 61, 149-178. [CrossRef] 
84. Tzounis, X.; Rodriguez-Mateos, A.; Vulevic, J.; Gibson, G.R.; Kwik-Uribe, C.; Spencer, J.P. Prebiotic evaluation of cocoa-derived flavanols in healthy humans by using a randomized, controlled, double-blind, crossover intervention study. Am. J. Clin. Nutr. 2011, 93, 62-72. [CrossRef] [PubMed]

85. Sanders, M.E.; Merenstein, D.J.; Reid, G.; Gibson, G.R.; Rastall, R.A. Probiotics and prebiotics in intestinal health and disease: From biology to the clinic. Nat. Rev. Gatroenterol. Hepatol. 2019, 16, 605-616. [CrossRef] [PubMed]

86. De Albuquerque, T.M.R.; Borges, C.W.P.; Cavalcanti, M.T.; Lima, M.S.; Magnani, M.; de Souza, E.L. Potential prebiotic properties of flours from different varieties of sweet potato (Ipomoea batatas L.) roots cultivated in Northeastern Brazil. Food Biosci. 2020, $36,100614$. [CrossRef]

87. Massa, N.M.L.; Menezes, F.N.D.D.; de Albuquerque, T.N.R.; de Oliveira, S.P.A.; Lima, M.S.; Magnani, M.; de Souza, E.L. Effects of digested jabuticaba (Myrciariajaboticaba (Vell.) Berg) by-product on growth and metabolism of Lactobacillus and Bifidobacterium indicate prebiotic properties. LWT Food Sci. Technol. 2020, 131, 109766. [CrossRef]

88. Adeyinka, A.; Richard, F. Application of phytochemical extracts and essential oils in food products: A review. Int. J. Biotechnol. Food Sci. 2015, 3, 31-35.

89. Gyawali, R.; Hayek, S.A.; Ibrahim, S.A. Plant extracts as antimicrobials in food products: Mechanisms of action extraction methods, and applications. In Handbook of Natural Antimicrobials for Food Safety and Quality; Woodhead Publishing Series in Food Science, Technology and Nutrition; Taylor, T.M., Ed.; Woodhead Publishing: Cambridge, UK, 2015; pp. $31-47$.

90. Packiavathy, I.A.S.V.; Agilandeswari, P.; Musthafa, K.S.; Pandian, S.K.; Ravi, A.V. Antibiofilm and quórum sensing inhibitory potential of Cuminum cyminum and its secondary metabolite methyl eugenol against Gram negative bacterial pathogens. Food Res. Int. 2012, 45, 85-92. [CrossRef]

91. García-Díez, J.; Alheiro, J.; Pinto, A.L.; Soares, L.; Falco, V.; Franqueza, M.J. Behaviour of food-borne pathogens on dry cured sausage manufactured with herbs and spices essential oils and their sensorial acceptability. Food Control 2016, 59, 262-270. [CrossRef]

92. Chan, E.W.C.; Chan, H.J.; Lim, J.E.; Yik, S.H.; Tan, S.F.; Goh, P.C.; Yap, K.Y.; Yee, S.Y. Effects of different cooking methods on the bioactivities of some spices. Emir. J. Food Agric. 2015, 27, 610-616. [CrossRef]

93. Martínez-Graciá, C.; Gonzalez-Bermudez, C.A.; Cabellero-Valcarcel, A.M.; Santaella-Pascual, M.; Frontela-Saseta, C. Use of herbs and spices for food preservation: Advantages and limitations. Food Sci. 2015, 6, 38-43. [CrossRef]

94. Gutfinger, T. Polyphenols in Olive Oils. J. Am. Oil Chem. Soc. 1981, 58, 966-968. [CrossRef]

95. Pothirat, C.; Petsuk, N.; Deesomchok, A.; Theerakittikul, T.; Bumroongkit, C.; Liwsrisakun, C.; Inchai, J. Clinical characteristic, management in real world practice and long term survival among COPD patients of northern Thailand COPD Club members. J. Med. Assoc. Thai 2007, 90, 653-662.

96. Siracusa, L.; Saija, A.; Cristani, M.; Cimino, F.; D’Arrigo, M.; Trombetta, D.; Rao, F.; Ruberto, G. Phytocomplexes from liquorice (Glycyrrhiza glabra L.) leaves-Chemical characterization and evaluation of their antioxidant, anti-genotoxic and anti-inflammatory activity. Fitoterapia 2011, 82, 546-556. [CrossRef] [PubMed]

97. Buenguer, J.; Ackermann, H.; Jentzsch, A.; Mehling, A.; Pfitzner, I.; Reiffen, K.A.; Schroeder, K.R.; Wollenweber, U. An inter laboratory comparaison of methods used to assess antioxidant potentials. Int. J. Cosmet. Sci. 2006, 28, 135-146. [CrossRef] [PubMed]

98. Clinical and Laboratory Standards Institute, M100-S. Performance Standards for Antimicrobial Susceptibility Testing; Seventeenth Informational Supplement Clinical Laboratory Standards Institute: Wayne, IL, USA, 2008. 